\title{
Androgen-dependent messenger RNA(s) related to secretory proteins in the mouse epididymis
}

\author{
N. B. Ghyselinck, C. Jimenez, Y. Courty and J. P. Dufaure \\ Biologie Cellulaire, Université Blaise Pascal et CNRS UA 360, Les Cézeaux, \\ 24 avenue des Landais, 63177 Aubière Cedex, France
}

\begin{abstract}
Summary. Total RNA from mouse epididymides was translated in a cell-free system derived from rabbit reticulocyte lysate. The androgen dependence of a highly represented mRNA(s) was detected. This mRNA(s) encoded for a band of $M_{\mathrm{r}} 26000$ vizualized by denaturing gel electrophoresis (SDS-PAGE). No other mouse sexual tissues (testis, vas deferens and seminal vesicle), liver, kidney or striated muscle presented such a band. Furthermore, this mRNA(s) was restricted to the caput epididymidis. Two-dimensional gel electrophoresis (2D-PAGE) showed that this band of $M_{\mathrm{r}} 26000$ was composed of 6 basic polypeptides. This translated protein may correspond to a newly synthesized secretory protein of $M_{\mathrm{r}} 24000$.

The concentration of translatable mRNA(s) encoding for the band of $M_{\mathrm{r}} 26000$ dropped to $31 \%$ of the normal level at 3 days after castration and to $7 \%, 20$ days later. Administration of testosterone to 30-day-castrated mice partly reversed these changes: $32 \%$ of the control value was reached after 10 days of treatment. Accumulation of this mRNA(s) was also just detectable ( $7 \%$ of the mature level) at 10 days of age. The high levels attained by 20 days of age ( $60 \%$ of the control value) suggest that the greatest increase of accumulation for this mRNA(s) occurs during the prepubertal period.
\end{abstract}

Keywords: mouse; epididymis; castration; ontogeny; mRNA(s)

\section{Introduction}

The mammalian epididymis is an androgen-dependent organ through which spermatozoa undergo a progressive series of morphological and physiological changes (Bedford, 1975) resulting in the ability to fertilize the oocyte (Orgebin-Crist et al., 1975; Orgebin-Crist \& Jahad, 1982). These sperm changes which are referred to as the 'maturation process' are under androgenic control of the epithelium and require RNA and protein synthesis (Orgebin-Crist \& Jahad, 1978). In rodents, specific epididymal proteins have been identified (Cameo \& Blaquier, 1976; Garberi et al., 1979; Brooks \& Higgins, 1980; Jones et al., 1980). Some are associated with the sperm surface (Lea et al., 1978; Voglmayr et al., 1980; Moore, 1981; Olson \& Danzo, 1981).

Modulation of epididymal gene expression by hormones has been investigated (Brooks, 1981). Most evidence to date suggests that androgens control protein synthesis by regulating gene expression at transcriptional and/or post-transcriptional levels (D'Agostino et al., 1980; Brooks et al., 1986a, b; Morel et al., 1986; Brooks, 1987a; Courty et al., 1987). The mechanism for the mouse epididymis is not known although several androgen-dependent proteins have been identified (Flickinger et al., 1986; Holland \& Orgebin-Crist, 1988), amongst which some bind specifically to the surface of spermatozoa (Devine \& Carroll, 1984; Murphy \& Carroll, 1984, 1987; Lakoski et al., 1988).

The caput epididymidis in the mouse is an active site of synthesis and secretion for numerous proteins (Flickinger, 1979, 1981; Fain-Maurel et al., 1981, 1983; Flickinger, 1983; Devine \& 
Carroll, 1985). Furthermore, it is generally admitted that most of the physiological changes of the gametes are initiated in this epididymal region (Courot, 1981; Orgebin-Crist \& Fournier-Delpech, 1982; Voglmayr \& Dacheux, 1983). Hence, as a preliminary to studies on the regulation of gene expression, it was decided to investigate the effects of testosterone on mRNA activity in the mouse caput epididymidis.

\section{Materials and Methods}

Animals. Tissues were isolated from male mice of the Swiss strain (CDI: Charles River, Cléon, France) killed under different physiological conditions. Adult mice ( 60 days) were castrated by the abdominal route. Androgenic replacement was by subcutaneous injection twice daily $(75 \mu \mathrm{g} /$ injection) for 10 days with testosterone heptylate (Theramex Laboratories, Monaco) dissolved in sesame oil. For total RNA isolation, at each age and in each physiological state, up to 40 pooled organs were excised free from adhering adipose tissue, immediately frozen in liquid nitrogen and then stored at $-80^{\circ} \mathrm{C}$. Just before freezing, the epididymides were cut into the 3 regions of the caput, corpus and cauda (see Fig. 1b).

Isolation of total RNA. Total cellular RNA was isolated by the guanidium extraction procedure of Cathala et al. (1983) in which up to $500 \mathrm{mg}$ tissue were homogenized in $8 \mathrm{ml} 3 \mathrm{M}$-guanidium monothiocyanate, $50 \mathrm{~mm}-\mathrm{Tris}-\mathrm{HCl}$ pH 7.5, $10 \mathrm{~mm}$-EDTA, $10 \%$ (v/v) $\beta$-mercaptoethanol. Total RNA was precipitated using $3.5 \mathrm{M}-\mathrm{LiCl}$ at $4^{\circ} \mathrm{C}$ for $36 \mathrm{~h}$. After centrifugation at $11000 \mathrm{~g}$ for $90 \mathrm{~min}$ the pellet was redissolved in $10 \mathrm{mM}$-Tris-HCl pH $7 \cdot 5,1 \mathrm{mM}$-EDTA, $0 \cdot 1 \%$ (v/v) sodium dodecyl sulphate (SDS) by vortexing. Proteins were then recovered by phenolic extraction and finally total RNA was precipitated in $250 \mathrm{~mm}$-sodium acetate with 2 volumes of ethanol at $-20^{\circ} \mathrm{C}$.

In-vitro translation of RNA. Total RNA $(10 \mu \mathrm{g})$ was translated in a cell-free system derived from rabbit reticulocyte lysate treated with micrococcal nuclease (Promega Biotec, Madison, WI, USA) and with added yeast tRNA (5 ng/ $\mu$ : GIBCO BRL, Cergy Pontoise, France). Incubation was carried out with human placental ribonuclease inhibitor (HPRI or RNasine, $1 \mathrm{U} / \mu \mathrm{l}$ : Promega Biotec) for $1 \mathrm{~h}$ at $30^{\circ} \mathrm{C}$ according to the manufacturer's instructions, in the presence of $60 \mu \mathrm{Ci}\left[{ }^{35} \mathrm{~S}\right]$ methionine (sp. act. $1000 \mathrm{Ci} / \mathrm{mmol}$ : Amersham, Bucks, UK).

Whole cell protein synthesis. To obtain newly synthesized proteins, 4 epididymides were freshly excised and minced finely in ice-cold sterile phosphate-buffered saline to remove spermatozoa and luminal secretions. Tissue fragments of $50 \mathrm{mg}$ were incubated for $5 \mathrm{~h}$ at $37^{\circ} \mathrm{C}$ in a $\mathrm{CO}_{2}$-enriched atmosphere in $0.5 \mathrm{ml}$ Eagle's minimum essential medium (MEM) without methionine (GIBCO BRL) containing $100 \mu \mathrm{Ci}\left[{ }^{35} \mathrm{~S}\right]$ methionine (sp. act. $1000 \mathrm{Ci} / \mathrm{mmol}$ : Amersham).

The tissues were then rinsed with ice-cold $120 \mathrm{~mm}$-Tris $-\mathrm{HCl}$ buffer $\mathrm{pH} 7.2$ and homogenized in the same buffer in the presence of $0 \cdot 1 \% \operatorname{SDS}(\mathrm{v} / \mathrm{v})$. After centrifugation at $12000 \mathrm{~g}$ for $10 \mathrm{~min}$, supernatants were collected and stored at $-80^{\circ} \mathrm{C}$. Total soluble proteins were estimated by the method of Lowry et al. (1951) using bovine serum albumin as a standard.

Protein electrophoresis and autoradiography. Incorporated radioactivity in newly synthesized proteins and in translated products was determined by protein precipitation with $10 \%$ trichloracetic acid and measurement with scintillation liquid (Beckman EP40) in a scintillation spectrophotometer (Beckman LS9800, Beckman Instruments, Gagny, France). Protein synthesis or translation was investigated by analysis of labelled proteins or translated products on $15 \%$ polyacrylamide slab gels in the presence of $0.1 \%(\mathrm{v} / \mathrm{v})$ SDS (SDS-PAGE) according to the method of Laemmli (1970). Denatured samples containing 150000 d.p.m. were loaded and one-dimensional electrophoresis was performed for $6 \mathrm{~h}$ at $25 \mathrm{~mA}$ in Tris-glycine buffer $\mathrm{pH} 8 \cdot 3$. Two-dimensional electrophoresis (2D-PAGE) consisting of a non-equilibrium $\mathrm{pH}$ gradient electrophoresis (NEpHGE) followed by denaturing polyacrylamide gel electrophoresis were also performed according to O'Farrell (1975). In the first dimension, samples containing 500000 d.p.m. were loaded in the presence of $\mathrm{pH}$ 3-10 ampholines (Servalyt: Tebu, Le Perray-en-Yvelines, France) and of a non-denaturing zwitterionic detergent according to Hjelmeland (1980).

Gels were then stained with Coomassie brilliant blue R250 (0.25\% in 50\% methanol, $10 \%$ acetic acid) for $30 \mathrm{~min}$ and destained for $12 \mathrm{~h}$ in $20 \%$ methanol, $5 \%$ acetic acid. For 2D-PAGE, fluorography of gels was performed using $20 \%$ PPO in DMSO (w/v) as an enhancer (Laskey \& Mills, 1975). After drying, gels were exposed for 1 month at $-80^{\circ} \mathrm{C}$ on an X-Omat film (Kodak, Rochester, NY, USA) in the presence of intensifying screens (Dupont Cronex $\mathrm{Li}+$, Wilmington, DE, USA). The absorbance of one-dimensional gels electrophoresis autoradiography was also measured spectrophotometrically at $580 \mathrm{~nm}$ (LKB Instruments, Orsay, France).

\section{Results}

\section{Evidence for a major $m R N A(s)$ species restricted to the caput epididymidis}

Individual mRNA species can be studied by translating them in a cell-free system and analysing the pattern of radiolabelled translated products on SDS-PAGE. Total RNA was isolated from 
whole epididymis, testis, vas deferens, seminal vesicle, liver, kidney and striated muscle of normal adult mice and was translated in the rabbit reticulocyte lysate. Autoradiography of the gel electrophoresis indicated that a major band of $M_{\mathrm{r}} 26000$ seemed to be present in the epididymis only (Fig. 1a, lane I). Total RNA was isolated from the caput, corpus and cauda epididymidis (Fig. 1b). SDS-PAGE analysis of translated peptides from $10 \mu \mathrm{g}$ total RNA of each part showed that the band of $M_{\mathrm{r}} 26000$ was more abundant in the caput (Fig. 1c, lane 1) than in other parts of the epididymis (Fig. 1c, lanes 2 and 3). Three bands of $M_{\mathrm{r}} 22000,25000$ and 27000 were translated in the corpus (Fig. 1c, lane 2), while another major band of $M_{\mathrm{r}} 28000$ was apparent in the cauda (Fig. lc, lane 3).

(a)

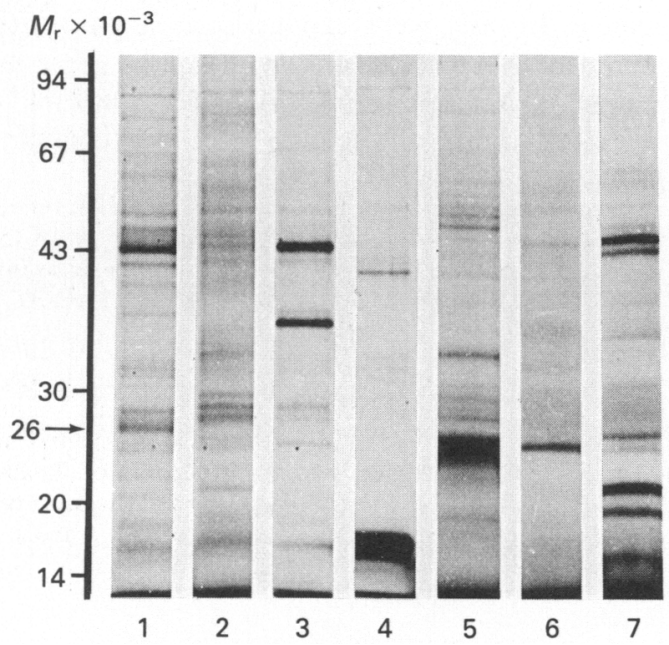

(b)

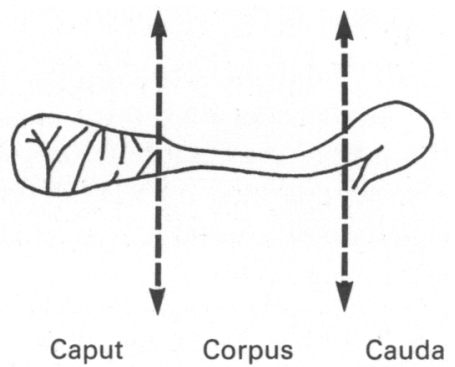

(c) $M_{\mathrm{r}} \times 10^{-3}$

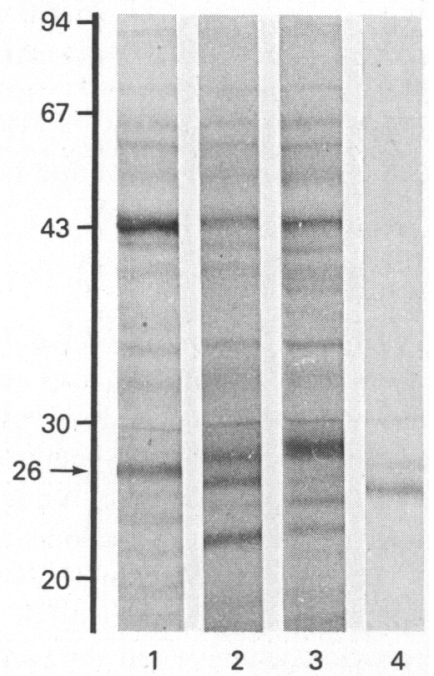

Fig. 1. Tissue specificity and epididymal distribution for the mRNA(s) encoding for the protein at $M_{\mathrm{r}} 26000$. (a) Autoradiography analysis of radiolabelled peptides translated, in rabbit reticulocyte lysate, from $10 \mu \mathrm{g}$ total RNA prepared from adult male mice whole epididymis (lane 1), testis (lane 2), vas deferens (lane 3), seminal vesicle (lane 4), liver (lane 5), kidney (lane 6) and striated muscle (lane 7). Arrow indicates the position of the major epididymal band of $M_{\mathrm{r}} 26000$. (b) Subdivisions of the epididymis into the caput, the corpus and the cauda. (c) Autoradiography analysis of radiolabelled peptides translated, in rabbit reticulocyte lysate, from $10 \mu \mathrm{g}$ total RNA isolated from the caput (lane 1), corpus (lane 2) and cauda (lane 3) epididymidis. Lane 4 was the lysate control without added RNA. Arrow indicates the position of the band of $M_{\mathrm{r}} 26000$. 


\section{Androgenic regulation of the $m R N A(s)$ encoding for the protein at $\mathrm{M}_{r} 26000$}

To investigate whether testosterone regulated the accumulation of this translatable mRNA(s) species, $10 \mu \mathrm{g}$ total RNA extracted from the caput epididymidis of normal adult mice, and mice castrated for 30 days or castrated for 30 days and then treated for 10 days with testosterone, were translated in the cell-free system. Analysis of labelled translated peptides on SDS-PAGE followed by autoradiography revealed that testosterone regulated the concentration of this mRNA(s). Autoradiographs were scanned on a spectrophotometer. The band at $M_{\mathrm{r}} 26000$ accounted for $34 \%$ of the total $\left[{ }^{35}\right.$ S]methionine incorporated for the normal adult mice (Fig. 2a, lane 1). After castration, the proportion declined to $2.5 \%$ (Fig. 2a, lane 2) but was partly restored to $13 \%$ (Fig. $2 \mathrm{a}$, lane 3 ) by testosterone administration.

Total RNA was prepared from the caput epididymidis of adult mice ( 60 days), adult mice castrated for $3,10,20$ or 30 days and from mice castrated for 30 days then treated with testosterone for 10 days. After translation of $10 \mu \mathrm{g}$ total RNA in the cell-free system containing $\left[{ }^{35} \mathrm{~S}\right] \mathrm{methionine}$, the radioactivity incorporated in the band of $M_{\mathrm{r}} 26000$ was investigated by analysing the electrophoresis autoradiographs on a spectrophotometer. Results were expressed as a percentage of pre-castration values (Fig. 2b). Specific translatable mRNA(s) encoding for the band of $M_{\mathrm{r}} 26000$ fell by about $70 \%$ during the first 3 days after castration and represented about $5 \%$ of normal by 30 days castration. Administration of testosterone to these long-term castrated mice resulted in a partial restoration in translatable mRNA(s) concentration ( $32 \%$ of normal value).

\section{Accumulation of the $m R N A(s)$ encoding for the protein at $\mathrm{M}_{r} 26000$ during post-natal development}

Total RNA $(10 \mu \mathrm{g})$ from the caput epididymidis of young mice aged 10, 20 and 30 days and from adult mice (60 days) was translated. The concentration of specific translatable mRNA(s) encoding for the band of $M_{\mathrm{r}} 26000$ was assessed as described previously. Results are expressed as a percentage of normal adult values (Fig. 2c). Translatable mRNA(s) for the band of $M_{\mathrm{r}} 26000$ was already detectable at 10 days of age, representing about $5 \%$ of the normal values. Thereafter, the level of mRNA(s) rose sharply to reach about $60 \%$ of the control at 20 days of age and attaining values characteristic of adulthood between 20 and 60 days of age.

\section{Comparison of the protein at $\mathrm{M}_{r} 26000$ with proteins synthesized in the caput epididymidis}

To correlate the translated band of $M_{\mathrm{r}} 26000$ with epididymal proteins, protein synthesis was investigated. Fragments of caput epididymidis from adult mice, adult mice castrated for 30 days and adults castrated for 30 days before treatment with testosterone for 10 days were incubated in vitro in the presence of $\left[{ }^{35} \mathrm{~S}\right]$ methionine. Proteins were separated on SDS-PAGE and gels were stained with Coomassie blue. No accumulated protein of $M_{\mathrm{r}} 26000$ was stained. Gels were then autoradiographed to indicate labelled proteins.

Unexpectedly, no band of $M_{\mathrm{r}} 26000$ was detected amongst the newly synthesized proteins but a major androgen-dependent band of $M_{\mathrm{r}} 24000$ was identified. Direct SDS-PAGE of the media from the incubation sets revealed the presence of a particularly prominent protein of $M_{\mathrm{r}} 24000$ for the normal epididymis, suggesting a secreted protein (data not shown). To attempt correspondence between the bands of $M_{\mathrm{r}} 26000$ and $M_{\mathrm{r}} 24000$, two-dimensional gel electrophoresis was performed and labelled proteins or translated peptides were detected by fluorography. The pattern of peptides translated from total RNA extracted from mice of different androgenic status (Fig. 3a) showed that the major band of $M_{\mathrm{r}} 26000$ consisted of 6 basic spots with $\mathrm{pH}_{\mathrm{i}}$ values varying from 6 to 9 (Fig. 3a, slab 1). The 2nd and 4th spots $\left(\mathrm{pH}_{\mathrm{i}}=6.5\right.$ and $\left.\mathrm{pH}_{\mathrm{i}}=7\right)$ were not completely suppressed in 30-daycastrated males (Fig. 3a, slab 2) and the first spot $\left(\mathrm{pH}_{\mathrm{i}}=6\right)$ was not restored by testosterone in our conditions (Fig. 3a, slab 3). For the newly synthesized proteins, the band of $M_{\mathrm{r}} 24000$ consisted of 6 basic peptides with $\mathrm{pH}_{\mathrm{i}}$ values varying from 7 to 9 (Fig. 3b, slab 1). The 1st and 3rd spots 
(a) $M_{r} \times 10^{-3}$
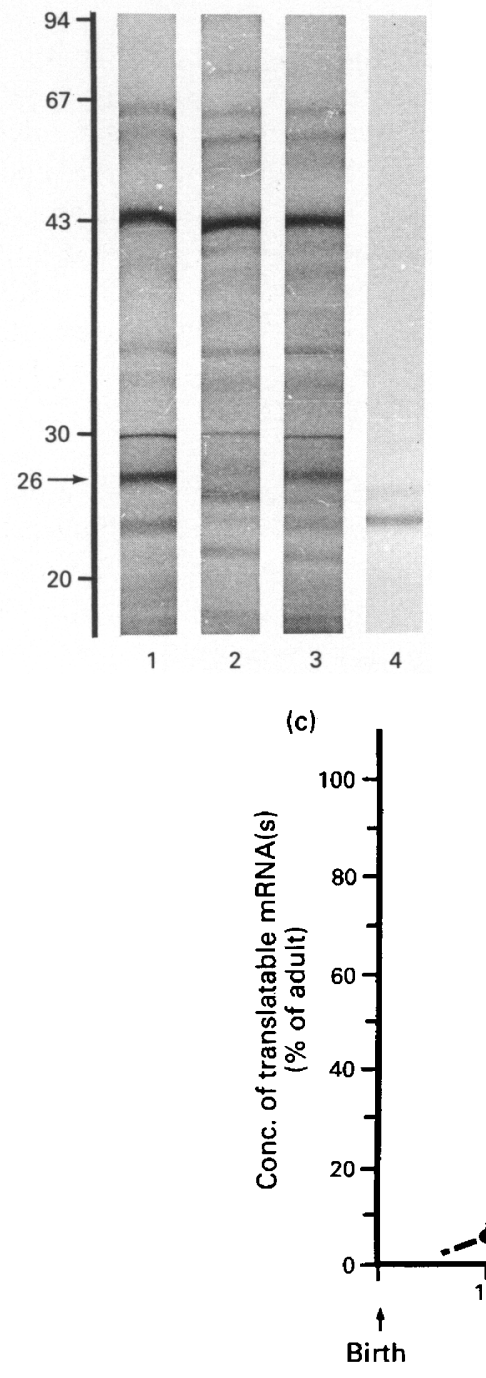

(b)

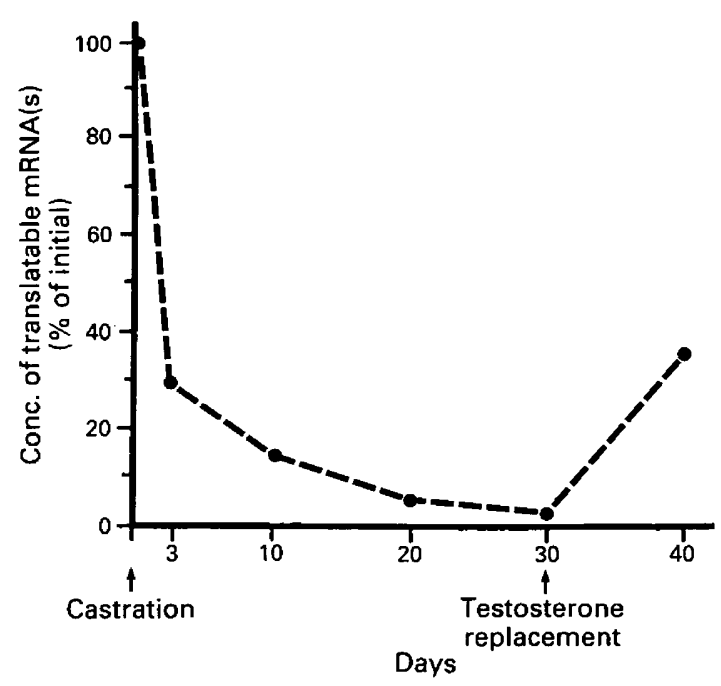


$\left(\mathrm{pH}_{\mathrm{i}}=7\right.$ and $\left.\mathrm{pH}_{\mathrm{i}}=8\right)$ were not completely suppressed by castration for 30 days (Fig. $3 \mathrm{~b}$, slab 2$)$ and the first spot $\left(\mathrm{pH}_{\mathrm{i}}=7\right)$ was not restored by testosterone treatment for 10 days (Fig. 3b, slab 3).
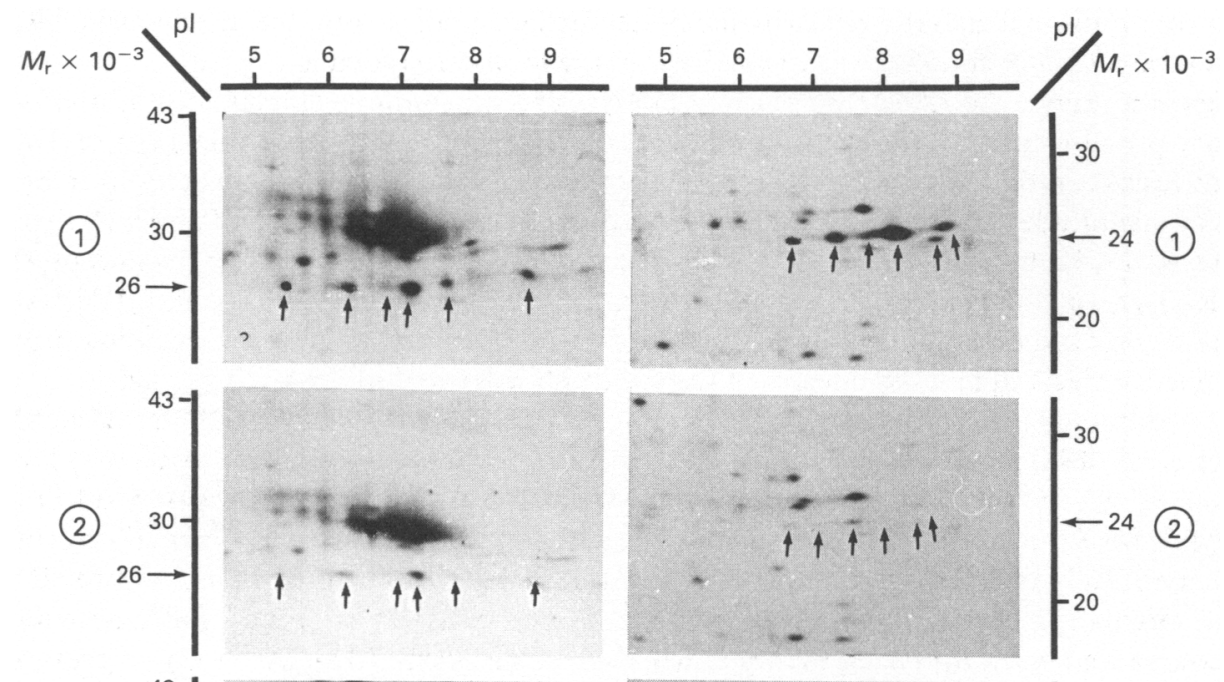

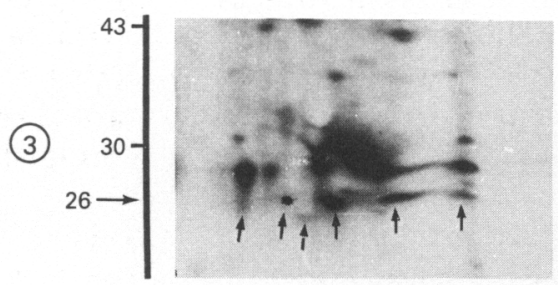

(a)

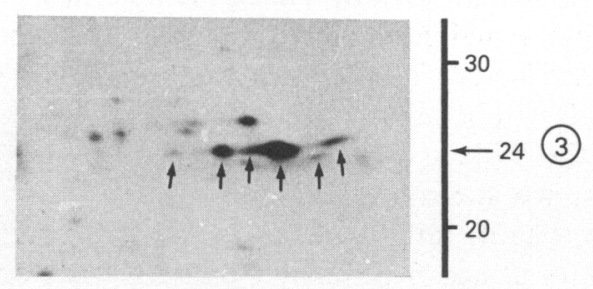

(b)

Fig. 3. Two-dimensional fluorography analyses of radiolabelled peptides. (a) Peptides translated, in rabbit reticulocyte lysate, from $10 \mu \mathrm{g}$ total RNA extracted from the caput epididymidis of normal adult mice (slab 1), mice castrated for 30 days (slab 2), and mice castrated for 30 days then treated with testosterone for 10 days (slab 3). Arrows indicate the position of the basic spots for the androgen-dependent protein of $M_{\mathrm{r}} 26000$. (b) Proteins newly synthesized in vitro, in the presence of ${ }^{35}$ S]methionine, by the caput epididymidis of normal mice (slab 1), mice castrated for 30 days (slab 2) and mice castrated for 30 days and then treated with testosterone for 10 days (slab 3). Arrows indicate the position of the basic spots corresponding to the secretory androgen-dependent protein of $M_{\mathrm{r}} 24000$.

\section{Discussion}

The epididymis is a complex organ with pronounced regional variations in structure and functions (Hamilton, 1975). It is now assumed that the main events of the sperm maturational changes occur in the caput epididymidis (Courot, 1981; Orgebin-Crist \& Fournier Delpech, 1982) and the particular importance of androgen-regulated epididymal secretory proteins in promoting those sperm changes appears to be well established (Orgebin-Crist \& Jahad, 1979). Nevertheless, in the mouse little is known about hormonal regulation of epididymal protein synthesis (Holland \& Orgebin-Crist, 1988). These reasons led us to investigate whether individual mRNA(s) species corresponding to secretory proteins were regulated by testosterone in the mouse epididymis. The present results indicate an abundant mRNA(s) sequence specific to the mouse epididymis which is translatable in vitro into a protein band of $M_{\mathrm{r}} 26000$. This mRNA(s) was restricted to the caput 
epididymidis, suggesting that it encoded for a major protein which could serve a specific function within the epididymal environment. The results described in this paper suggested also that the relative concentration of this $\mathrm{mRNA}(\mathrm{s})$ sequence was controlled by testosterone, making it a good marker of hormonal action that will facilitate further studies into the mechanism by which testosterone regulates specific protein synthesis in the mouse epididymis.

After castration, the rate of decrease in mRNA concentration is similar to that observed for secretory proteins in two other well studied androgen-dependent tissues, namely the prostate and seminal vesicle. In those organs, specific species of mRNAs are reduced in concentration by 2 or 3 orders of magnitude during the first week after castration (Parker et al., 1980; Page \& Parker, 1982; Mills et al., 1987a, b, c). In the mouse epididymis we detected a $70 \%$ reduction of concentration of the mRNA(s) for the band of $M_{r} 26000$ at 3 days after castration. A decline in mRNA(s) levels after castration indicates that the androgenic control of synthesis of the corresponding proteins is determined, at least in part, by control of the steady state level of mRNAs. It remains to be shown whether additional translation control, as observed in the seminal vesicle during sexual maturation (Kistler et al., 1981), also operates. The failure to obtain full restoration of mRNA(s) levels for the band of $M_{\mathrm{r}} 26000$ should be emphasized. A similar situation has been described in the rat epididymis for Proteins B and C (Brooks, 1987a) and the synthesis of an epididymal protein of $M_{\mathrm{r}}$ 23500 is not fully restored by testosterone in castrated mice (Holland \& Orgebin-Crist, 1988). In the rat, circulating testosterone concentrations are not sufficient to obtain full maintenance of morphology and metabolism of the epididymal proximal parts (Brooks, 1983), suggesting that these epididymal regions are dependent on some other testicular factors. The nature of these additional factors is unknown but complex multihormonal control has been suspected (Brooks, 1987b). It will be of interest to determine whether other hormones or testicular factors are able to restore the mRNA(s) concentration. With a cDNA probe it will be possible to investigate all these control phenomena in more detail.

Translatable mRNA(s) for the band at $M_{\mathrm{r}} 26000$ were detectable in the epididymis of mice of 10 days of age. Then they increased dramatically, coinciding with the increase in epididymal testosterone content which occurs in mice aged 20 days (Jean-Faucher et al., 1985). At this age the epididymal epithelium differentiates into its various cell types (Abou-Haila \& Fain-Maurel, 1985). The concentration of the most important translatable mRNA(s) therefore appeared to increase during the prepubertal period and to correspond to the cellular differentiation step, as described for the mRNAs of the rat epididymal Proteins B, C and D (Brooks, 1987a), of the mouse prostate p12 and p25 (Mills et al., 1987a, b, c) or for the rat SVSII in seminal vesicle (Dodd et al., 1986). The seminal vesicle mRNA is present in early development but is apparently not efficiently translated in vivo into proteins (Kistler et al., 1981). Such results led us to believe that a cell-free translation system would provide evidence for in-vitro translatable mRNA(s) sequences. We cannot exclude that untranslatable mRNA(s) for the protein at $M_{\mathrm{r}} 26000$ could be present in the early development of young mice. A cDNA probe will permit further investigations.

Using epididymal tissue slices incubated with $\left[{ }^{35}\right.$ S $]$ methionine, we were not able to identify a protein at $M_{\mathrm{r}} 26000$, but a major secretory protein band $\left(M_{\mathrm{r}} 24000\right)$ regulated by testosterone was detected. No other androgen-dependent protein was detected in this molecular weight range. When analysed by 2D-PAGE the protein band of $M_{\mathrm{r}} 24000$ appeared to be composed of 6 basic peptides and the translated band of $M_{\mathrm{r}} 26000$ also consisted of 6 basic spots. These spots had different $\mathrm{pH}_{\mathrm{i}}$ values but the same pattern as those of the newly synthesized protein of $M_{\mathrm{r}} 24000$, and the hormonal regulation was similar. If the protein of $M_{\mathrm{r}} 26000$ and the protein of $M_{\mathrm{r}} 24000$ are related, an explanation is needed for the difference in relative mobility. Many secretory proteins have been demonstrated to be synthesized as presecretory proteins containing an $N$-terminal sequence of $M_{\mathrm{r}} \approx 2000$ referred to as the 'signal peptide' when their mRNA is translated in a cellfree system (Milstein et al., 1972; Blobel \& Dobberstein, 1975). Since the additional amino acids are usually cleaved in vivo but not in the reticulocyte lysate, the peptides translated in vitro would migrate with a reduced relative mobility. Therefore, the protein of $M_{\mathrm{r}} 26000$ could correspond to 
the presecretory precursor incompletely processed into the authentic secretory protein of $M_{\mathrm{r}}$ 24000 . To account for the 'signal peptide' hypothesis, translation was performed in the presence of heterologous dog pancreatic microsomal membranes. Unfortunately no difference in the relative mobility of the translated protein at $M_{\mathrm{r}} 26000$ was detected (data not shown).

Antibodies against the proteins are currently being raised to study whether the translated protein of $M_{\mathrm{r}} 26000$ and the synthesized protein of $M_{\mathrm{r}} 24000$ are related.

This work was supported by a grant from the CNRS (UA 360: Organisation et expression du genome des eucaryotes) and by the Fondation pour la Recherche Médicale.

\section{References}

Abou-Haila, A. \& Fain-Maurel, M.A. (1985) Post-natal differentiation of the enzymatic activity in the mouse epididymis. Int. J. Androl. 8, 441-458.

Bedford, J.M. (1975) Maturation, transport and fate of spermatozoa in the epididymis. In Handbook of Physiology, sec. 7, Endocrinology, Vol. 5, Male Reproductive System, pp. 303-317. Eds D. W. Hamilton \& R. O. Greep. American Physiological Society, Washington D.C.

Blobel, G. \& Dobberstein, B. (1975) Transfer of protein across membranes. I Presence of proteolytically processed and unprocessed nascent immunoglobulin light chains on membrane-bound ribosomes of murine myeloma. J. Cell Biol. 67, 835-851.

Brooks, D.E. (1981) Metabolic activity in the epididymis and its regulation by androgens. Am. Physiol. Rev. $61,515-555$.

Brooks, D.E. (1983) Effects of androgens on protein synthesis and secretion in various regions of the rat epididymis, as analysed by two-dimensional gel electrophoresis. Molec. cell. Endocr. 29, 255-270.

Brooks, D.E. (1987a) Developmental expression and androgenic regulation of the mRNA for major secretory proteins of the rat epididymis. Molec. cell. Endocr. 53, 59-66.

Brooks, D.E. (1987b) The major androgen regulated secretory proteins of the rat epididymis bear sequence homology with members of the $\alpha_{2 u}$ globulin superfamily. Biochem. Int. 14, 235-240.

Brooks, D.E. \& Higgins, S.J. (1980) Characterization and androgen dependence of proteins associated with luminal fluid and spermatozoa in the rat epididymis. J. Reprod. Fert. 59, 363-375.

Brooks, D.E., Means, A.R., Wright, E.J., Singh, S.P. \& Tiver, K.K. (1986a) Molecular cloning of the cDNA for androgen-dependent sperm coating glycoproteins secreted by the rat epididymis. Eur. J. Biochem. 161, 13-18

Brooks, D.E., Means, A.R., Wright, E.J., Singh, S.P. \& Tiver, K.K. (1986b) Molecular cloning of the cDNA for two major androgen dependent secretory proteins of $18.5 \mathrm{kD}$ synthesized by the rat epididymis. J. biol. Chem. 26, 4956-4961.

Cameo, M.S. \& Blaquier, J.A. (1976) Androgen controlled specific proteins in rat epididymis. $J$. Endocr. 69, 47-55.

Cathala, G., Savouret, J.F., Mendez, B., West, B.L., Karin, M., Martial, J.A. \& Baxter, J.D. (1983) A method for isolation of intact, translationally active ribonucleic acid. $D N A 2,329-335$.
Courot, M. (1981) Transport and maturation of spermatozoa in the epididymis of mammals. Prog. Reprod. Biol. 8, 67-79.

Courty, Y., Morel, F. \& Dufaure, J.P. (1987) Characterization and androgenic regulation of major mRNAs coding for epididymal proteins in a lizard (Lacerta vivipara). J. Reprod. Fert. 81, 443-451.

D'Agostino, A., Jones, R., White, R. \& Parker, M.G. (1980) Androgenic regulation of messenger RNA in rat epididymis. Biochem. J. 190, 505-512.

Devine, K.M. \& Carroll, J. (1984) Changes in the surface of mouse spermatozoa during their passage through the epididymis. Biochem. Soc. Trans. 12, 441-442.

Devine, K.M. \& Carroll, J. (1985) Peptide synthesis by the murine epididymis. Biochem. Soc. Trans. 13, 506-507.

Dodd, J.G., Kreis, C., Sheppard, P.C., Hamel, A. \& Matusik, R. (1986) Effects of androgens on mRNA for a secretory protein of dorsolateral prostate and seminal vesicles. Molec. cell. Endocr. 47, $191-200$.

Fain-Maurel, M.A., Dadoune, J.P. \& Alfonsi, M.F. (1981) High resolution autoradiography of newly formed proteins in the epididymis after incorporation of tritiated amino acids. Archs Androl. 6, 249-266.

Fain-Maurel, M.A., Dadoune, J.P. \& Jauzein-Leau, F. (1983) Protein secretion by the principal cells of the mouse epididymis evidenced by in vitro incorporation of tritiated leucine. Reprod. Nutr. Dev. 23, 175-182.

Flickinger, C.J. (1979) Synthesis, transport and secretion of proteins in the initial segment of the mouse epididymis studied by electron microscope radioautography. Biol. Reprod. 20, 1015-1030.

Flickinger, C.J. (1981) Regional differences in synthesis, intracellular transport, and secretion of protein in the mouse epididymis. Biol. Reprod. 25, 871-883.

Flickinger, C.J. (1983) Synthesis and secretion of glycoprotein by the epididymal epithelium. $J$. Androl. 4, 157-161.

Flickinger, C.J., Herr, J.C. \& Ertl, K.E. (1986) Identification and isolation of epididymal luminal proteins of the mouse. $J$. Androl. 7, 163-168.

Garberi, J.C., Kohane, A.C., Cameo, M.S. \& Blaquier, J.A. (1979) Isolation and characterization of specific rat epididymal proteins. Molec. cell. Endocr. 13, 73-82.

Hamilton, D.W. (1975) Structure and function of the epithelium lining the ductuli efferentes, ductus epididymis and ductus deferens in the rat. In Handbook of Physiology, sec. 7, Endocrinology, Vol. 5, Male 
Reproductive System, pp. 259-301. Eds D. W. Hamilton \& R. O. Greep. American Physiological Society, Washington D.C.

Hjelmeland, L.M. (1980) A non denaturing switterionic detergent for membrane biochemistry: design and synthesis. Proc. natn. Acad. Sci. U.S.A. 77, 6368-6370.

Holland, M.K. \& Orgebin-Crist, M.C. (1988) Characterization and hormonal regulation of protein synthesis by the murine epididymis. Biol. Reprod. 38, 487-496.

Jean-Faucher, C., Berger, M., de Turckheim, M., Veyssiere, G. \& Jean, C. (1985) Testosterone and dihydrotestosterone levels in the epididymis, vas deferens and prepucial gland of mice during sexual maturation. Int. J. Androl. 8, 44-57.

Jones, R., Brown, C.R., Von Glos, K.I. \& Parker, M.G. (1980) Hormonal regulation of protein synthesis in the rat epididymis: characterization of androgen dependent and testicular fluid dependent proteins. Biochem. J. 188, 664-676.

Kistler, M.K., Ostrowski, M.C. \& Kistler, W.S. (1981) Developmental regulation of secretory proteins synthesis in the rat seminal vesicle. Proc. natn. Acad. Sci. U.S.A. 78, 737-741.

Laemmli, U.K. (1970) Cleavage of structural proteins during the assembly of the head of bacteriophage T4. Nature, Lond. 227, 680-685.

Lakoski, K.A., Carron, C.P., Cabot, C.L. \& Saling, P.M. (1988) Epididymal maturation and the acrosome reaction in the mouse sperm. Response to zona pellucida develops coincident with modification of M42 antigen. Biol. Reprod. 38, 221-233.

Laskey, R.A. \& Mills, A.D. (1975) Quantitative film detection of ${ }^{3} \mathrm{H}$ and ${ }^{14} \mathrm{C}$ in polyacrylamide gels by fluorography. Eur. J. Biochem. 56, 335-341.

Lea, O.A., Petrusz, P. \& French, F.S. (1978) Purification and localization of acidic epididymal glycoprotein (AEG): a sperm coating protein secreted by the rat epididymis. Int. J. Androl. 2, 592-597.

Lowry, O.H., Rosebrough, N.J., Farr, A.L. \& Randall, R.J. (1951) Protein measurement with Folin phenol reagent. J. biol. Chem. 193, 265-275.

Mills, J.S., Needham, M. \& Parker, M.G. (1987a) Androgen regulated expression of a spermine binding protein gene in mouse ventral prostate. Nucl. Acid. Res. 15, 7709-7724

Mills, J.S., Needham, M. \& Parker, M.G. (1987b) A secretory protease inhibitor requires androgens for its expression in male sex accessory tissues but is expressed constitutively in pancreas. $E M B O \mathrm{~J} .6$, 3711-3717.

Mills, J.S., Needham, M., Thompson, T.C. \& Parker, M.G. (1987c) Androgen regulated expression of secretory protein synthesis in mouse ventral prostate. Molec. cell. Endocr. 53, 111-118.

Milstein, C., Brownlee, G.G., Harrison, T.M. \& Mathews, M.B. (1972) A possible precursor of immunoglobulin light chains. Nature, Lond. 239, $117-120$.

Moore, H.D.M. (1981) Glycoprotein secretion of the epididymis in rabbit and hamster. Localization on epididymal spermatozoa and the effect of specific antibodies on fertilization in vivo. J. exp. Zool. 215, 77-85.

Morel, F., Courty, Y., Mesure, M. \& Dufaure, J.P. (1986) Effects of castration on the epididymis of a nonmammalian vertebrate: evolution of morphology, protein synthesis, and of specific mRNA levels. Biol. Cell 58, 201-210.

Murphy, G.J.P. \& Carroll, J. (1984) Immunofluorescence studies on spermatozoa from the mouse epididymis. Biochem. Soc. Trans. 12, 442-443.

Murphy, G.J.P. \& Carroll, J. (1987) Detection and localization of antigens on the surface of mouse spermatozoa. Biochem. J. 241, 379-387.

O'Farrell, P.H. (1975) High resolution two-dimensional electrophoresis of proteins. J. biol. Chem. 250, 4007-4021.

Olson, G.E. \& Danzo, B. (1981) Surface changes in rat spermatozoa during epididymal transit. Biol. Reprod. 24, 431-443.

Orgebin-Crist, M.C. \& Fournier-Delpech, S. (1982) Evidence for maturational changes during epididymal transit. J. Androl. 3, 429-433.

Orgebin-Crist, M.C. \& Jahad, N. (1978) The maturation of rabbit epididymal spermatoza in organ culture: inhibition by antiandrogens and inhibitors of ribonucleic acid and protein synthesis. Endocrinology 103, $46-53$.

Orgebin-Crist, M.C. \& Jahad, N. (1979) The maturation of rabbit epididymal spermatozoa in organ culture: stimulation by epididymal cytoplasmic extracts. Biol. Reprod. 21, 51 I-515.

Orgebin-Crist, M.C. \& Jahad, N. (1982) Sperm-egg interaction: evidence for maturational changes during epididymal transit. J. Androl. 3, 429-433.

Orgebin-Crist, M.C., Danzo, B.J. \& Davies, J. (1975) Endocrine control of the development and maintenance of sperm fertilizing ability in the epididymis. In Handbook of Physiology, sect. 7, Endocrinology, Vol. 5, Male Reproductive System, pp. 319-338. Eds D. W. Hamilton \& R. O. Greep. American Physiological Society, Washington D.C.

Page, M.J. \& Parker, M.G. (1982) Effects of androgen on transcription of rat prostatic binding protein genes. Molec. cell. Endocr. 27, 343-355.

Parker, M.G., White, R. \& William, J.G. (1980) Cloning and characterization of androgen dependent mRNA from ventral prostate. J. biol. Chem. 255, 6996-7001.

Voglmayr, J.K. \& Dacheux, J.L. (1983) Surface change sequence in ram spermatozoa during epididymal transit. Biol. Reprod. 28 136-139.

Voglmayr, J.K., Fairbanks, G., Jackowitz, M.A. \& Colella, J.R. (1980) Post-testicular developmental changes in the ram sperm cell surface and their relationship to luminal fluid proteins of the reproductive tract. Biol. Reprod. 22, 655-667.

Received 26 July 1988 